\title{
Legume-cereal forage mixtures for silage 1. Effect of pea variety, maturity and sowing density of mixture on dry matter yield and silage chemical composition
}

\author{
A. Urbański' and F. Brzóska² \\ Research Institute of Animal Production \\ ${ }^{\prime}$ Experimental Farm, Lipowa \\ ${ }^{2}$ Department of Feed Science and Animal Products \\ 32-083 Balice, Poland
}

(Received 17 July 1995; accepted 12 April 1996)

\begin{abstract}
The effect of variety, maturity and sowing density of pea in mixturcs with spring wheat and Italian ryegrass grown for silage on dry matter yield, level of nutrients in green forage and chemical composition and quality of silage was studied. The average dry matter yield of the forage mixtures for the factors and vegetative seasons studied was $7.4 \mathrm{tha}^{-1}$. The participation of pea plants in mixtures before ensiling was from 31 to $45 \%$ and that of spring wheat and Italian ryegrass from 39 to $46 \%$ and from 13 to $23 \%$, respectively. The dry matter in green forage from the mixtures averaged $250 \mathrm{~g} \mathrm{~kg}^{-1}$ and in silage $224 \mathrm{~g} \mathrm{~kg}^{-1}$. Rumen degradability of dry matter of the of silage during 2 to $48 \mathrm{~h}$ incubation ranged from 52 to $81 \%$. No significant effect of pea variety and mixture sowing density on yield, dry matter and nutrients contents in green fodder and chemical composition of the silage $(P \geqslant 0.05)$ was found. A significant effect of pea maturity and year of growth of the forages on content of nutrients in the green forage and chemical composition of the silage was found $(P \leqslant 0.01)$.
\end{abstract}

KEY WORDS: pea, spring wheat, Italian ryegrass, forages, nutrients, rumen, degradability

\section{INTRODUCTION}

Spring wheat, pea plants or legume-cereal forage mixtures are alternative plants for silages in areas where growing maize may by risky. The problem of the

\footnotetext{
${ }^{2}$ Corresponding author
} 
growth and ensiling of whole cereal plants is well known (Kirchgessner et al., 1989; Bergen et al., 1991; Michna and Poloczek, 1993). Studies have also been conducted on the growth of pea plants for silage but because of the lodging of the plants and losses during harvest the species has not found practical use (Brundage et al.; 1979, Potts, 1980, 1982; Faulkner, 1989; Stryk, 1990). An agrotechnical factor enabling the growth of pea plants for silages is the use of spring crops as a support for pea plants. Preliminary studies made by Urbański and Brzóska (1991) and Ostrowski and Daczewska (1993) indicate that mixtures of pea plants and spring wheat together with companion crop of grass or lucerne are characterized by relatively high nutritive value.

The aim of the present study was to determine the effect of the major agrotechnical factors in growth of forage mixtures on yield, nutritive value of green forage and chemical composition and nutrient degradability of silages from the mixtures.

\section{MATERIAL AND METHODS}

Growth experiments were carried out in 1988 and 1989 in the Experimental Station of Research Institute for Animal Production at Lipowa, $360 \mathrm{~m}$ above sea level, on podsolic type mineral soil, $\mathrm{pH}$ 5.7.

\section{Yield and chemical composition of forages}

Tri-factor field experiments were carried in split-plot $(5 \times 15 \mathrm{~m})$ system, in four replication for each factor. The material used was legume-cereal-grass mixtures composed of pea (varieties Ramir, Koral, Opal), spring wheat (var. Henika) and Italian ryegrass (var. Gaza). The amounts used for sowing per ha ${ }^{-1}$ in both years were:

low seed rate (pea 150 , wheat $52.5 \mathrm{~kg}$ )

medium seed rate (pea 200 , wheat $70 \mathrm{~kg}$ )

high seed rate (pea 250 , wheat $87.5 \mathrm{~kg}$ )

Italian ryegrass was sown at a constant value of $45 \mathrm{~kg} \mathrm{ha}^{-1}$, irrespective of the sowing density of the main components. Sowing of the mixtures was preceded by mineral fertilization, in the first year $56 \mathrm{~kg} \mathrm{~N}, 92 \mathrm{~kg} \mathrm{P}_{2} \mathrm{O}_{5}$ and $150 \mathrm{~kg} \mathrm{~K}_{2} \mathrm{O} \mathrm{ha}^{-1}$, in the second year 51,92 and $142 \mathrm{~kg} \mathrm{ha}^{-1}$, respectively. Seeds of pea and spring wheat were cross sown separately with the use of cereal seeder, with a distance between rows of $15 \mathrm{~cm}$. Pea was sown $4-5 \mathrm{~cm}$ deep and wheat $3 \mathrm{~cm}$ deep. Italian ryegrass was sown by broadcasting. After sowing the plots were harrowed. During growth no mechanical or chemical protective measures were used. The mixtures 
were cut and ensilaged at three stages of pea maturity: pod setting (A), flat pods (B) and full pods with milk and dough maturity of the seeds (C). The first date of harvest was between July 6 and 15, the second and third between July 12 and 23, and between July 20 and 29, respectively. After harvest the mixtures the aftercrop of grass was fertilized with $51 \mathrm{~kg} \mathrm{~N} \mathrm{ha}^{-1}$ and then cut twice $35-40$ days apart.

\section{Che. ical composition and rumen degradability of silages}

In both vegetative seasons the mixtures were used to make silages in laboratory scale. Directly after cutting the green forage was cut into chaff $2-4 \mathrm{~cm}$ long and placed in $3 \mathrm{dcm}^{3}$ fermentation silos. The silos were then closed in a manner allowing the escape of excess fermentation products but preventing access of air. The silages were stored for 60 days in darkened room at $10^{\circ} \mathrm{C}$ after which $\mathrm{pH}$, chemical composition, quality and dry matter degradability in the rumen were determined.

\section{Analysis}

Yield of the mixtures and aftercrop of grass was determined by cutting and weighing the mass of the plants from $33 \%$ of the surface of each plot $\left(25 \mathrm{~m}^{2}\right)$. The mixtures were harvest when $50 \%$ pea plants were at a specific stage of maturity. At each of the dates after cutting of the plants about $3 \mathrm{~kg}$ fresh weight was collected and its dry matter content and botanical composition determined. The remainder was dried in air dryer for chemical analyses. Dry matter was determined at $105^{\circ} \mathrm{C}$ and its content in silages was corrected for volatile substances (Dulphy and Demarquilly, 1981). The nutrients content in the green forage was determined using conventional methods (AOAC, 1990) and that of monosaccharides colorimetrically (Deriaz, 1961). The level of short chain fatty acids in the silages was determined in aqueous extracts using the method of Lepper (VDLUFA, 1988) and that of ammonia-N by Kieldahl's distillation method with the use of magnesium oxide (Skulmowski, 1974). The quality of silage was estimated by Flieg-Zimmer's method.

Dry matter degradability in the rumen was determined according to Ørskov et al. (1980) on three mature bullocks with $70 \mathrm{~mm}$ diameter rumen cannulas, fed twice each days with a dose composed of meadow hay and ground barley in ratio $2: 1$, supplemented with mineral mixture and salt. Five gram samples of silages were incubated in polyamide bags for $2,4,8,16$ and $48 \mathrm{~h}$.

Statistical analysis were carried out by variance analysis and Tukeys test (Elandt, 1964). 


\section{RESULTS}

Atmospheric conditions and yield of forage mixtures

The amount and distribution of rainfall and air temperature during the course of the study is given in Table 1. The yield of dry matter of the mixtures, averaged for the studied factors, was $7.4 \mathrm{t} \mathrm{DM} \mathrm{ha}^{-1}$ and the yield together with aftercrop of grass $9.9 \mathrm{t} \mathrm{ha}^{-1}$ (Table 2 ). The effect of pea variety and mixture sowing density on yield and DM in the green forage was not significant $(P \geqslant 0.05)$.

\section{Botanical and chemical composition of forages}

The participation of pea in biomass of green forage ranged from 31 to $45 \%$, that of spring wheat from 39 to $46 \%$ and that Italian ryegrass from 13 to $23 \%$ (Table 3). The mutual proportions of the plant species in the mixtures depended above all on sowing density. Increased density of pea and spring wheat was accompanied by reduced content of grass in the biomass. A significant effect of season and maturity on content of pea in the mixtures and content of dry matter and nutrients in the green forage of the mixtures was observed $(P \leqslant 0.01)$. Crude protein content in the biomass of the mixtures averaged $140.4 \mathrm{~g} \mathrm{~kg}^{-1}$ and that of crude fibre $311.4 \mathrm{~g} \mathrm{~kg}^{-1} \mathrm{DM}$. No significant effect of pea variety and mixture sowing density on protein content, ether extract, crude fibre and ash in the forage was found. Maturation of the pea plants was accompanied by reduced protein content in the forage. The crude fibre content remained unchanged. The average monosaccharide content in the green forage of the mixtures was $94.2 \mathrm{~g} \mathrm{~kg}^{-1} \mathrm{DM}$ and the studied agrotechnical factors as well as year of cultivation did not significantly affect their level.

\section{Chemical composition of silage, rumen degradability}

The content of dry matter in 206 silages averaged $224.2 \mathrm{~g} \mathrm{~kg}^{-1}$. The $\mathrm{pH}$ was 4.2 (Table 4). No significant effect of pea variety and mixture sowing density on acid content in the silages or participation of ammonia- $\mathrm{N}$ and total-N in the silages was determined. The silages evaluated with the use of Flieg-Zimmer's scale scored 66 and 84 points in the two different years. The studied factors did not significantly affect the quality of the silages.

Degradation of silage DM in the rumen after 2 to $48 \mathrm{~h}$ incubation was from 52.0 to $80.8 \%$, and $73.8 \%$ after $24 \mathrm{~h}$ (Table 5). No significant effect of pea variety and mixture sowing density on rumen degradability of DM of silage was found. However, differences in the degradability of the silages in the consecutive vegetative seasons were significant $(\mathrm{P} \leqslant 0.01)$. 
TABLE 1

Air temperature and rainfall during two vegetation periods

\begin{tabular}{|c|c|c|c|c|}
\hline \multirow{2}{*}{ Month } & \multicolumn{2}{|c|}{1988} & \multicolumn{2}{|c|}{1989} \\
\hline & $\begin{array}{l}\text { Air temperature } \\
{ }^{0} \mathrm{C}\end{array}$ & $\begin{array}{l}\text { Rainfall } \\
\mathrm{mm}\end{array}$ & $\begin{array}{l}\text { Air temperature } \\
{ }^{0} \mathrm{C}\end{array}$ & $\begin{array}{l}\text { Rainfall } \\
\mathrm{mm}\end{array}$ \\
\hline April & 7.2 & 35.1 & 9.7 & 101.1 \\
\hline May & 14.5 & 66.5 & 12.7 & 110.3 \\
\hline June & 15.2 & 119.6 & 14.4 & 144.6 \\
\hline July & 18.9 & 72.7 & 17.5 & 74.9 \\
\hline Average year temperature & 8.3 & - & 8.9 & - \\
\hline Total & - & 829.4 & - & 788.5 \\
\hline
\end{tabular}

TABLE 2

Dry matter yicld of forage mixtures and grass cutch crop, $t$ ha ${ }^{-1}$

\begin{tabular}{|c|c|c|c|c|c|c|}
\hline \multirow{2}{*}{\multicolumn{2}{|c|}{ Treatment }} & \multirow{2}{*}{$\begin{array}{l}\text { Forage mixture } \\
\text { DM yield }\end{array}$} & \multirow{2}{*}{$\begin{array}{l}\text { DM content } \\
\mathrm{g} \mathrm{kg}^{-1}\end{array}$} & \multicolumn{2}{|c|}{ Grass cutch crop DM yicld } & \multirow{2}{*}{$\begin{array}{c}\text { Total } \\
\text { DM yield }\end{array}$} \\
\hline & & & & cut 1 st & cut 2 nd & \\
\hline \multicolumn{7}{|c|}{ Variety } \\
\hline \multicolumn{2}{|c|}{ Ramir } & 7.60 & 246.6 & 1.41 & 1.06 & 10.07 \\
\hline \multicolumn{2}{|c|}{ Koral } & 7.67 & 254.6 & 1.56 & 1.05 & 10.27 \\
\hline \multicolumn{2}{|c|}{ Opal } & 6.99 & 248.5 & 1.42 & 0.97 & 9.37 \\
\hline \multicolumn{2}{|c|}{$P \leqslant 0.01$} & NS & NS & NS & NS & NS \\
\hline \multicolumn{7}{|c|}{ Sowing density } \\
\hline \multicolumn{2}{|c|}{$\begin{array}{l}\text { Sowing dens } \\
\text { low }\end{array}$} & 7.15 & 246.1 & 1.63 & 1.05 & 9.82 \\
\hline \multicolumn{2}{|c|}{ medium } & 7.57 & 249.2 & 1.40 & 1.00 & 9.89 \\
\hline \multicolumn{2}{|c|}{ high } & 7.53 & 254.4 & 1.36 & 1.03 & 9.91 \\
\hline \multicolumn{2}{|c|}{$P \leqslant 0.01$} & NS & NS & NS & NS & NS \\
\hline \multicolumn{7}{|c|}{ Stage of maturity } \\
\hline \multicolumn{2}{|c|}{ A } & $6.54^{\mathrm{b}}$ & $204.4^{\mathrm{c}}$ & 1.60 & 1.14 & 9.28 \\
\hline \multicolumn{2}{|l|}{$\mathbf{B}$} & $7.74^{4}$ & $238.1^{b}$ & 1.39 & 1.02 & 10.15 \\
\hline \multicolumn{2}{|c|}{$\mathrm{C}$} & $7.97^{\mathrm{a}}$ & $307.2^{\mathrm{a}}$ & 1.40 & 0.93 & 10.29 \\
\hline \multicolumn{2}{|c|}{$P \leqslant 0.01$} & $* *$ & $* *$ & NS & NS & NS \\
\hline \multicolumn{7}{|c|}{ Year } \\
\hline \multicolumn{2}{|c|}{1988} & 7.14 & 246.6 & $1.27^{\mathrm{b}}$ & $1.06^{\mathrm{a}}$ & $9.47^{\mathrm{b}}$ \\
\hline \multicolumn{2}{|c|}{1989} & 7.67 & 253.2 & $1.66^{\mathrm{a}}$ & $0.99^{\mathrm{b}}$ & $10.34^{\mathrm{a}}$ \\
\hline \multicolumn{2}{|c|}{$P \leqslant 0.01$} & NS & NS & $* *$ & $* *$ & $* *$ \\
\hline \multicolumn{2}{|c|}{ Average } & 7.42 & 249.9 & 1.46 & 1.03 & 9.90 \\
\hline \multicolumn{2}{|c|}{$\mathrm{SD} \pm$} & 0.96 & 48.9 & 0.38 & 0.24 & 1.09 \\
\hline$* *$ & $-\mathrm{P} \leqslant$ & & & & & \\
\hline NS & - no & & & & & \\
\hline $\mathrm{SD} \pm$ & - sta & eviation mean & & & & \\
\hline $\mathrm{a}, \mathrm{b}, \mathrm{c}$ & - val & lumns for treatmen & s with the same & letters are no & fer significan & ly at $P \leqslant 0.01$ \\
\hline A & - po & & & & & \\
\hline B & - fla & & & & & \\
\hline $\mathrm{C}$ & $-\mathrm{ful}$ & th milk and doug & maturity & & & \\
\hline
\end{tabular}


TABLE 3

Botanical composition and nutrient content in forage mixture $\left(\mathrm{g} \mathrm{kg}^{-1}\right.$ of DM)

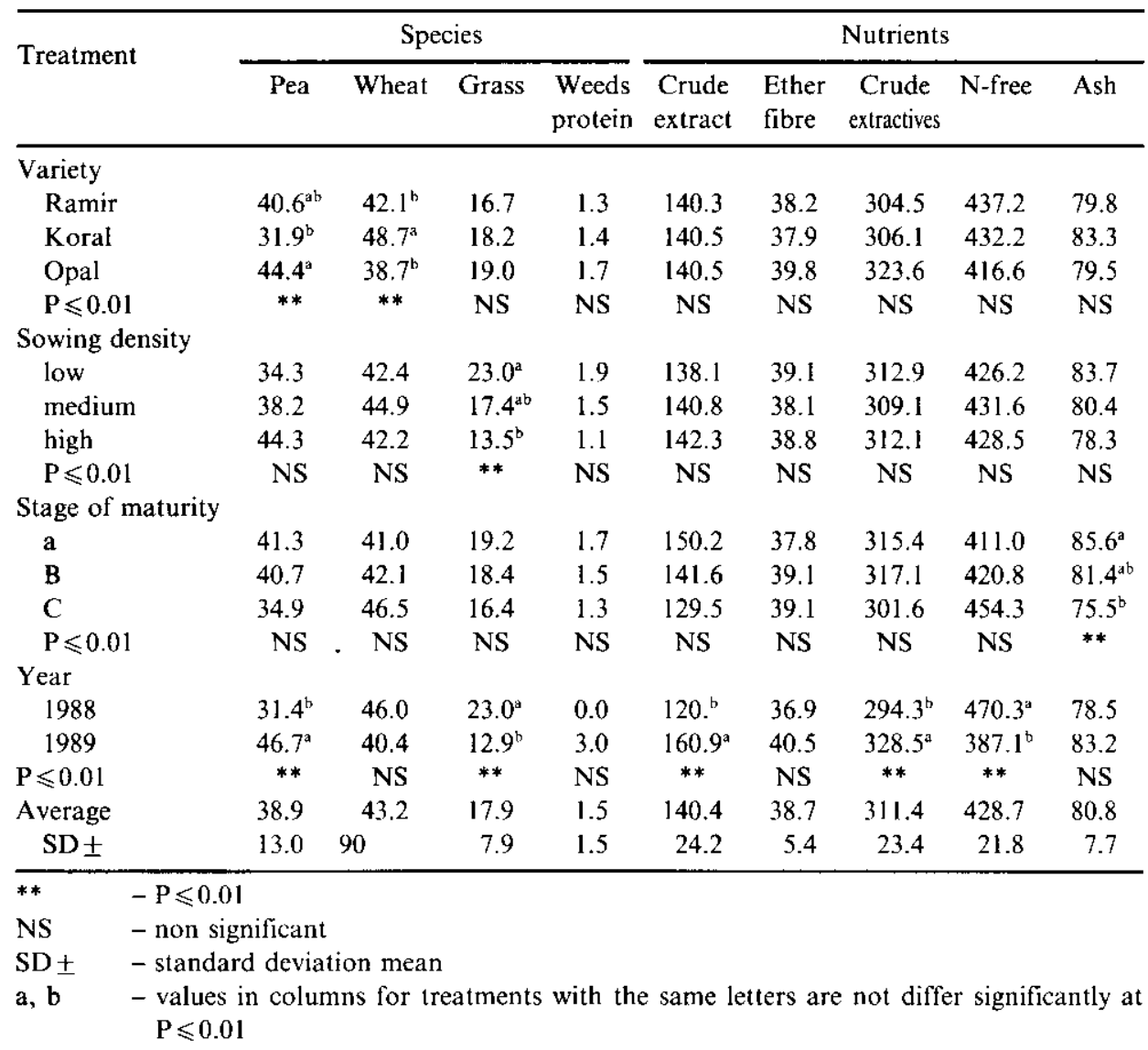

A, B, C - see table 2

\section{DISCUSSION}

The obtained results indicate that the yield of legume-cereal mixtures in highland conditions characterized by considerable precipitation and short vegetative season exceeds 7 tons of DM per ha and total yield including aftercrop of grass approximates $10 \mathrm{t}$ per ha, that is equals the yield of maize in years favouring its cultivation in these conditions. Similar yields of pea with spring wheat and companion crop of lucerne were obtained in the soil and climate conditions of Wielkopolska (Ostrowski and Daczewska, 1993). The yield of home varieties of pea grown for green forage is about $5.5 \mathrm{t}$, but for some varieties 
TABLE 4

Chemical composition of silages

\begin{tabular}{|c|c|c|c|c|}
\hline \multirow{2}{*}{\multicolumn{2}{|c|}{$\begin{array}{l}\text { Treatment DM content } \mathrm{pH} \\
\mathrm{g} \mathrm{kg}^{-1}\end{array}$}} & \multirow{2}{*}{\multicolumn{3}{|c|}{ 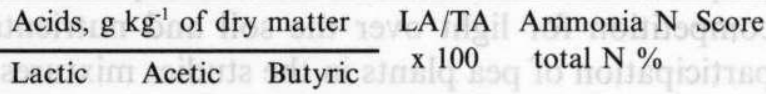 }} \\
\hline & & & & \\
\hline \multicolumn{5}{|l|}{ Variety } \\
\hline Ramir & $196.1^{\mathrm{b}}$ & $56.3 \quad 20.2$ & 69.2 & $5.65 \quad 72$ \\
\hline Koral & $219.5^{\mathrm{ab}}$ & 19.5 & 72.0 & 5.12 งो:73 \\
\hline Opal & $257.0^{\mathrm{a}}$ & 63.6 & 71.1 & 6.35 \\
\hline$P \leqslant 0.01$ & NS & NS & NS & NS \\
\hline \multicolumn{5}{|c|}{ Sowing density } \\
\hline low & 219.8 & 60.9 & 70.9 & 5.56 \\
\hline medium & 224.7 & 60.0 & 70.7 & 5.58 \\
\hline high & 228.2 & 19.7 & 71.1 & $5.98=75$ \\
\hline$P \leqslant 0.01$ & 159 NS & nS & NS & NS \\
\hline \multicolumn{5}{|c|}{ Stage of maturity } \\
\hline A & 213.4 & $69.2^{\mathrm{a}}$ & 69.3 & $7.74^{\mathrm{a}}$ \\
\hline B & 227.5 & $63.3^{\mathrm{a}}$ & 71.8 & $5.49^{\mathrm{b}}$ \\
\hline $\mathrm{C}$ & 231.8 & $49.1^{\mathrm{b}}$ & 72.5 & $3.89^{\mathrm{b}}$ \\
\hline $\mathrm{P} \leqslant 0.01$ & NS & $* * \quad$ Sif3 $\quad * *$ & NS & toj ** or NS \\
\hline \multicolumn{5}{|l|}{ Year } \\
\hline 1988 & 213.6 & $57.5^{\mathrm{b}}$ & $68.3^{b}$ & $4.09^{b}$ \\
\hline 1989 & 234.8 & $62.2^{\mathrm{a}}$ & $73.5^{\mathrm{a}}$ & $7.32^{\mathrm{a}}$ \\
\hline$P \leqslant 0.01$ & NS & NS & $* *$ & $* *$ \\
\hline Average & 224.2 & 19.6 & 71.0 & $5.71 \quad 75$ \\
\hline $\mathrm{SD} \pm$ & 50.0 & $\begin{array}{llll}12.5 & 12.5 & 1.7\end{array}$ & 8.5 & (1) 1.85 \\
\hline
\end{tabular}

LA/TA $\times 100$ - lactic acid/total acid ratio

NS - non significant

$\mathrm{SD} \pm$ - standard deviation mean

a, b - values in columns for treatments with the same letters are not differ significantly at $\mathrm{P} \leqslant 0.05$

A, B, C - see table 2

can exceed $7 \mathrm{t}$ DM per ha (Wiatr, 1989). Although no significant effect of pea variety on mixture yield was found, both domestic (Wiatr, 1989) and foreign (Potts, 1980) studies point differentiated yields of varieties cultivated in pure culture for green forage. Our results also indicate that mixture sowing density does not significantly affect DM yield, which may be of importance for costs of mixture cultivation. Significant differentiation of mixture yields in consecutive years of cultivation was determined. The greater amount of rainfall in April and May of the second year caused better germination of pea and significantly higher pea content in the mixtures and higher mixture yield. 
In the course of cultivation of multi-species mixtures of plants proper proportions between the botanical components are established as a result of competition for light over the soil and nutrients and water in the soil. The participation of pea plants in the studies mixtures did not exceed an average of $47 \%$ biomass for the studied factors and was modified by agrotechnical factors, particularly sowing density and pea maturity. Forage mixtures grown with low seed rate sowing contained less pea and more grass since a looser stand of the plants creates better conditions for growth of the latter, as shown in earlier studies (Walker et al., 1990). Differentation of home pea varieties grown for forage was 8 to 11 days to reach the stage of flat pod and was achieved between July 15 and August 5 (Wiatr, 1989).

The nutritive value and usefulness of the forage mixtures for silage was determined by dry matter content, protein and monosaccharides fermented by bacteria to organic acids (McDonald et al., 1991). Crude protein content in the mixtures of about $140 \mathrm{~g} \mathrm{~kg} \mathrm{DM}$ is much higher than in the case of maize but lower than in grass, lucerne and clover. Changes in the content of nutrients in forage are on the whole compatible with the results of Aman and Graham (1987) who studied the chemical composition of whole pea plants during its maturation and found that differences in the composition were a result of changes in the proportions of leaves to stems. Basing on monosaccharide analysis and structural analysis of peas plants and their morphological fractions, the authors concluded that the best date for the harvest and silage of whole pea plants is the stage of seed formation in the pods. It can be assumed that a similar process occurred in the course of our studies and concerned not only pea but also wheat. The results of our studies indicate that prolonging the date of the harvest of mixtures for silage to the stage of full pods does not reduce the quality of the silages. It can be assumed that this is due to the favourable effect of Italian ryegrass in the mixture biomass, which is characterized by high content of readily fermentable sugars (Brzóska et al, 1986). It is also important that agrotechnical factors do not significantly affect the content of nutrients in forage and silages from the mixtures and the relatively high dry matter content in the mixture at the filled pea pod stage can determine good quality of the silages. When the dry matter content in the forage is relatively high (about $30 \%$ ) its partial drying is not necessary and furthermore the escape of fermentation juices is limited (Woolford, 1984). The lower content of fermentation products in silages from forage mixtures cut in the last stage of pea maturity probably resulted from their higher dry matter content (McDonald et al., 1991). An advantageous feature of the studied silages is their low content of ammonia- $\mathrm{N}$, which reflects low degree of protein degradation during fermentation. The degree of DM degradability of the silages in the rumen is high and resembles that of the degradation of silages from grass and legumes (Van Straalen and Tamminga, 1990). Agrotechnical factors 
do not significantly affect its size. The studies silages were classified as of average protein content, with intermediate between maize and legume-grass ensiling capacity. Silages from legume-cereal mixtures with companion crop of Italian ryegrass and without addition of any preservatives or stimulators of fermentation should be regarded as good and the fermentation process occuring in them correct.

\section{CONCLUSIONS}

Mixtures of pea with wheat spring and companion crop of Italian ryegrass grown for silage in highland regions give a yield of dry matter, together with aftercrop of grass, equal to that of maize grown in those conditions.

Agrotechnical factors, i.e. pea variety and mixture sowing density can differentiate the yield but do not significantly affect the content of nutrients in the forage or the chemical composition and quality of the silage.

In respect of size of yield and chemical composition of the silages the best season for cutting the mixture is at the stage of full pods and milk and dough stages of the pea seeds.

\section{REFERENCES}

Åman P., Graham H., 1987. Whole-crop peas. I. Changes in botanical and chemical composition and rumen in vitro degradability during maturation. Anim. Feed Sci. Technol. 81, 15-31

AOAC, 1990. Official Methods of Analysis of the Association of Official Analytical Chemists. 15th edition, Arlington, Virginia, USA

Bergen W.G., Byrem T.M., Grant A.L., 1991. Ensiling characteristics of whote-crop small grains harvested at milk and dough stages. J.Anim. Sci. 69, 1766-1774

Brundage A.L., Taylor R.L., Burton V.L., 1979. Relative yicld and nutritive values of barley, oats and peas harvested at four successive dates for forage. J. Dairy Sci. 62, 740-745

Brzóska F., Żywczok H., Pasieka E., 1986. Nutrient content and digestibility of field-cultivated grasses (in Polish). Rocz. Nauk. Zoot. 13, 141-155

Deriaz R.E., 1961. The routine analysis of carbohydrates and lignin in herbage. J.Sci. Food Agric. 12, $152-160$

Dulphy J.P., Demarquilly C., 1981. Problemes particuliers aux ensilages, prevision de la valuer nutritive des aliments des ruminants. INRA Publ. pp. 81-104

Elandt R., 1964. Statistics in Expermental Agriculture (in Polish). PWRiL, Warszawa

Faulkner J.S., 1989. A comparison of faba beans and peas as whole-crop forage. Grass Forage Sci. 40, 161-169

Kirchgessner M., Heinzl W.E., Schwarz F.J., 1989. Futterwert von Gersten- und Weizen-Ganzplanzensilagen für Milchkühe bei unterschiedlichem Erntezeitpunkt.1. Mitt.: Inhaltsstoffe, Verdaulichkeiten und Energiegehalte. Wirtschaft. Futter, 35, 171-186 
McDonald P., Henderson N., Heron Sh., 1991. The Biochemistry of Silage. Chalcombe Publications, 2nd edition, UK

Michna G., Poloczek A., 1993. The effectiveness of barley and oat cultivation intended for a silage (in Polish). Rocz. Nauk. Zoot., Monogr. i Rozp. 32, 321-329

Ørskov E.R., DeB Hovell F.D., Mould F., 1980. The use of the nylon bag technique for the evaluation of feedstuffs. Tropical Anim. Prod. 5, 195-213

Ostrowski R., Daczewska M., 1993. The yield of cereal-legume mixtures under conditions of the Wielkopolska region and nutritive value of silages and dried forage for ruminants (in Polish). Rocz. Nauk. Zoot. 20, 157-169

Potts M.J., 1980. The influence of sowing date, harvest date and seed rate on the yield of forage peas. Grass Forage Sci. 35, 41-45

Potts M.J., 1982. The influence selected agronomic factors on the yield of forage peas. Grass Forage Sci. 37, 327-331

Skulmowski J., 1974. Methods of Estimation of Feedstuffs Composition and Quality (in Polish). PWRiL, Warszawa

Stryk J., 1990. Hrach v systemu GPS. Uroda 38, 72-73

Urbański A., Brzóska F., 1991. Pea-wheat-grass forage yield, nutritive value and silage chemical composition. Proceeding of International Symposium: Forage Preservation, Nitra, pp. 209-213

Van Straalen W.M., Tamminga S., 1990. Protein degradation of ruminant diets. In: J. Wiseman D.J.A. Cole (Editors). Feedstuff evaluation. Butterworths, London, pp. 55-67

VDLUFA, 1988. Die Chemische Untersuchung von Futtermitteln. VDLUFA- Verlag, Darmastadt Walker D.W., West C.P., Bacon R.K., Longer D.E., Turner K.E., 1990. Changes in forage yield and composition of wheat-ryegrass mixtures with maturity. J. Dairy Sci. 73, 1296-1303

Wiatr K., 1989. The results of experiments on breeding different plant varieties. Pea field bean (in Polish). 1988. COBOR (Editor), Słupia Wielka, 865

Woolford M.K., 1984. The Silage Fermentation. M.Bekker Inc., New York and Basel

\section{STRESZCZENIE}

Mieszanki strączkowo-zbożowe na kiszonkę. 1. Wpływ odmiany i fazy dojrzałości grochu oraz gęstości siewu mieszanek na plon suchej masy oraz sklad chemiczny kiszonek

Badano wpływ odmiany, fazy dojrzalości i gęstości siewu grochu w mieszankach z. pszenicą jarą i życicą wielokwiatową w uprawie na kiszonkę, na plon suchej masy, zawartość składników pokarmowych w zielonce oraz skład chemiczny i jakość kiszonek. Plon suchej masy mieszanek wynosił średnio dla badanych czynników i sezonów wegetacyjnych $7,4 \mathrm{t} \mathrm{ha}{ }^{-1}$. Udzial roślin grochu w mieszankach przed zakiszeniem wahał się od 31 do $45 \%$, pszenicy jarej od 39 do $46 \%$, a życicy wielokwiatowej od 13 do $23 \%$. Zawartość suchej masy w zielonce mieszanek wynosita średnio $250 \mathrm{~g} \mathrm{~kg}^{-1}$, a w kiszonkach z mieszanek średnio $224 \mathrm{~g} \mathrm{~kg}^{-1}$. Degradacja żwaczowa suchej masy kiszonek od 2 do 48 godzin inkubacji wynosiła od 52 do $81 \%$. Nie stwierdzono istotnego wpływu odmiany grochu i gęstości siewu mieszanek na wysokość plonu, zawartość suchej masy i składników pokarmowych w ziclonce oraz na skład chemiczny kiszonek $(P \geqslant 0.05)$. Stwierdzono istotny wpływ fazy dojrzałości grochu i roku uprawy mieszanek na zawartość składników pokarmowych w zielonce i skład chemiczny kiszonek $(P \leqslant 0.01)$. 